\title{
Driving Forces Behind Smart City Implementations - The Next Smart Revolution
}

\author{
Daniel Tokody ${ }^{1}$, György Schuster ${ }^{2}$ \\ ${ }^{1}$ Doctoral School on Safety and Security Sciences, Óbuda University \\ 1034 Budapest, Hungary \\ tokodi.daniel@bgok.hu \\ ${ }^{2}$ Instrument Technique and Automation Department Faculty of Electrical Engineering, \\ Óbuda University \\ 1034 Budapest, Hungary \\ schuster.gyorgy@kvk.uni-obuda.hu
}

\begin{abstract}
The present study examines the driving forces behind smart city implementations. Besides the results of international and European standardization efforts, the importance of holistic approach to cities and the issues of cities as complex systems will also be discussed. Furthermore, the relationship between cyber-physical systems and smart cities will be presented, and finally, certain conclusions will be drawn about the safety and security of smart cities. The urban structures and technological advances presented in this article mark the arrival of the next industrial revolution, which means that these intelligent and smart systems will cover all aspects of life.
\end{abstract}

Keywords: smart city, cyber-physical systems, intelligent systems, industrial revolution, holistic approach

\section{Introduction}

Our paper aims to analyse the driving forces of Smart City implementation considering the industrial or technological evolution and their goals and trying to answer the following Research Question. What is a real "Smart City"? In the further sections, we will reveal the depths of this concept, and the reason why the "Smart City" concept is so important for the society that it can be paralleled with the "industrial revolution" [1].

In Section 2 we provide an analysis of the long term effects of urbanisation in view of the data of current world population prospects. The expected population growth concentrated in urban areas is already causing serious social, technological, political, and other problems today, and it will be an even more significant factor in the future. Inequalities in our societies between the more developed and the poorer regions will continue to grow. These social tensions manifest themselves, among others, in the problems of migration or urbanisation. It is enough to consider, for example, the slums and ghettos of megacities. Further in this section, we also present how the idea of Smart City is discussed in the international scientific literature. 
Section 3 gives an overview of the most current holistic approach and Complexity theory implemented in Smart City models. We wish to underline the importance of thinking about smart city implementations as a system. It is not enough to develop a city in just one area, for example, from the aspect of environmental awareness, as there is an obvious interaction between different urban systems. Environmental awareness could not be achieved without the innovative solutions in transportation, and numerous other examples could be cited here.

In Section 4, we examine the present state and future trends of standardisation. We see standardisation as the result of considering this issue in its complexity, which helps integrate the many different ideas, technologies and solutions for a common purpose. The co-operation of different standardization bodies also plays a significant role in the promotion of a holistic approach in this topic.

In Section 5, we analyse a possible technical solution, that is, the relationship between the Smart City and the CPSs. Cyber-physical systems have already changed our societies to a significant extent. Today, it is impossible to imagine our lives without the conjunction of the physical and the virtual world. For instance, if we search for an address in a city, our first thought is to use a mobile device with a map application to find the right direction. There is a continuous development in our cities in the virtual elements complementing the physical environment.

In Section 6, through the vision of healthy and safe cities, we look at several questions concerning safety. The complex cyber world poses new challenges for urban systems, too. The meaning of safety is different in case of an autonomous car connected to the internet and in case of a traditional vehicle. These challenges are especially apparent in smart city implementations.

Finally, in the conclusion, we outline the achieved results, the limits of the research and the further work to be completed. The innovation, technological development and research potential involved in the creation of smart cities raise the prospect of a new smart liveable world bringing us the smart revolution of global development.

\section{Background to the research}

Since 1950 the world's population has grown exponentially by $1.2 \%$ on average each year. By 2007 half of humanity lived in cities. (See Fig. 2.) Over the past couple of years, this proportion has increased, and it will further grow in the future [2] [3].

According to statistics, there are around 200 countries in the world, while the number of cities can only be estimated. In 2012, the estimate number of cities with a population of over 2 million was 230. In 2013 there were 346 towns in Hungary. On the list of the 100 most populated cities, the first one is a megacity with a population over 37 million, while the last has slightly more than 3 million people. The population of Budapest was 1757618 in 2015, therefore it was not included in the list of the top 100 cities. The United Nations predicts that "The world population is projected to increase by more than one billion people within the next 15 years, reaching 8.5 billion in 2030, and to increase further to 9.7 billion in 2050 and 11.2 billion by 2100." [4] According to these projections, by 2030 the population of cities will increase as shown in Fig. 1. 


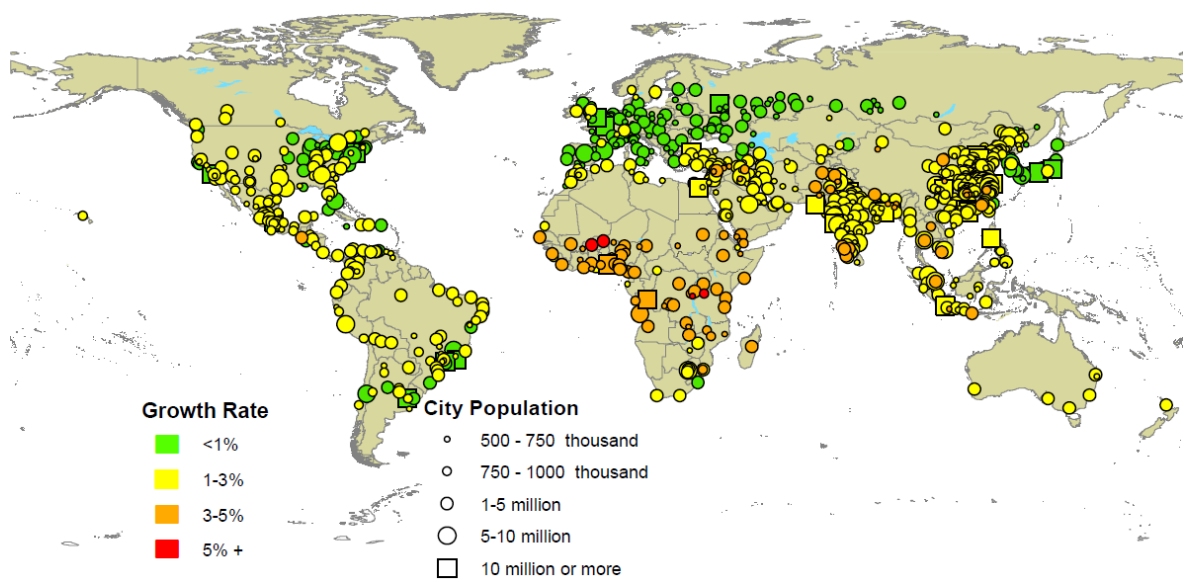

Fig. 1. "Growth rates of urban agglomerations by size class 2014- 2030" [5]

Fig. 2 shows the pace of urbanisation. As the UN states "Global urbanization is expected to continue, so that by 2050 , the world will be one-third rural ( 34 per cent) and two-thirds urban (66 per cent), roughly the reverse of the global rural-urban population distribution of the mid-twentieth century." [6]

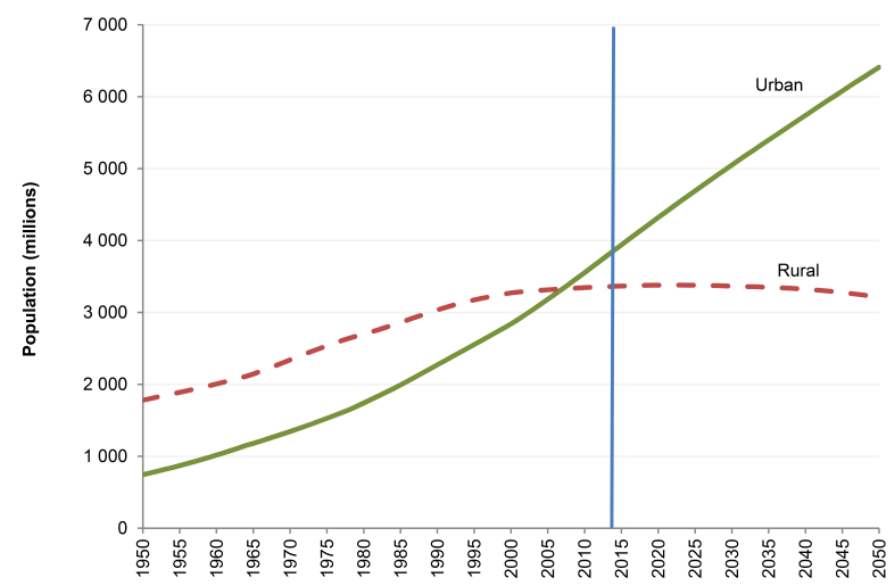

Fig. 2. The world's urban and rural populations, 1950-2050 [6]

Based on the data of the World Bank and of the national statistical offices, the following Fig. shows (see Fig. 3) the percentage of urban population within the total population between 2006 and 2014 in the world, in Europe and in Hungary. 


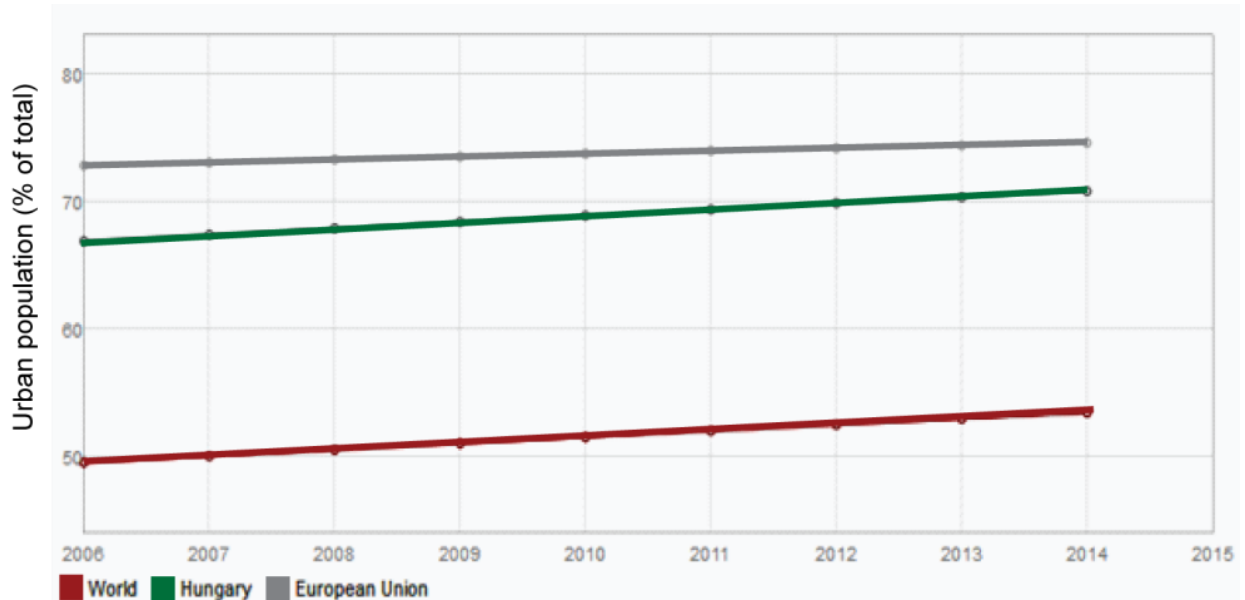

Fig. 3. The proportion (in percentage) of urban population within the total population in the world, in the EU and in Hungary [7]

As these different statistical data show, there is a continuous process of urbanization. The problems of humanity are concentrated in cities. Reasons for this can be traced to the density of population, the vast number of buildings and the complexity of infrastructure networks. Cities in themselves can also be described as networks, or the aggregate of systems and subsystems. The individual elements comprise a continuously changing artificial system, which functions like a living organism, and its technological complexity has significantly increased over the last decades. The process of "rapid urbanization is creating challenges and opportunities". [8] "While urbanization and the opportunities its citizens seek out are certainly not new — from the Middle Ages in Europe to the Industrial Revolution in the $1800 \mathrm{~s}$ - the rapid pace of today's migration is unprecedented. And the promise of the smart city is to help ensure that the economic and social benefits of urbanization are actually realized by curbing its negative consequences." [8]

The essence of the pioneer "smart" concept is the development of the common, synergic cooperation of different urban structures with the purpose of creating more liveable cities. Naturally, this will increase the complexity of the city as a system to such extent that cannot be predicted. This increased complexity and the connectivity of different systems will set new challenges both to experts and to the society as a whole.

"Smart is more user-friendly than intelligent, which is limited to having a quick mind and being responsive to feedback. Smart city is required to adapt itself to the user needs and to provide customized interfaces."[9]

The key idea of creating a Smart City is to "Focus on the urban dweller." Therefore the primary aim of all "smart" endeavours must be to ensure the well-being of people. Smart things (cities, materials, transport, etc.) are created in order to make human environment more liveable and to maintain it in the longer term (intelligent environments) [10]. All this should be achieved by providing users maximum benefits at the lowest possible cost. Improving and increasing the Quality of life (QoL) [11] for city dwellers are the main priority of all Smart City developments.

The development of "smart" cities might be seen as a rather utopian or idealistic aim [12]. The ranking of cities according to their smartness is very similar to the energy 
labels used for electrical goods. Like the $\mathrm{A}+++$ energy rating for these goods, the SMART +++ rating may be the highest to achieve for cities in some years. Such a ranking method is shown in Fig. 4.

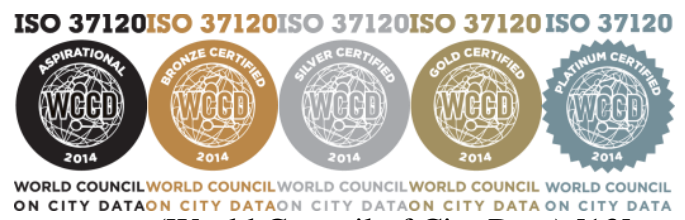

Fig. 4. Levels of city smartness (World Council of City Data) [13]

\section{A holistic approach to the complexity of the Smart City}

The meaning of the word "holism" is rooted in the Greek word "ő $\lambda$ o $\varsigma$ " ("holos"), which means "total" or "whole". In the context of Smart City research, the word "holistic" is used to refer to the integration of the whole structure related to this topic. Therefore, the concept of "Smart City" can only be considered more than the traditional urban approaches and individual initiatives, if it covers all the aspects related to cities. On the other hand, if it includes this inconceivable amount of factors, it will be a system of significant complexity. The complexity of systems falls within the subjects of the Complexity theory.

We must consider, however, whether the Complexity theory can be applied in the case of the Smart City.

The following key characteristics can be examined when looking at complex systems:

One of the characteristics of complex systems is self-organization, which means that at the initial state - which can be imagined as the combination of simple/traditional systems and complex systems - system elements will instinctively gain role in the creation of a system with new characteristics and new capabilities. It is important to note that the individual system elements are not able to develop such characteristics and they have not demonstrated these new characteristics before. Self-organization surpasses the limitations of predetermination, as such systems are characterized by development instead of stability. Another particularity of complex systems is their operation, which is based on the adaptivity to parallel processes. In these networked and de-centralized systems data-driven operation [14] is replaced by knowledge-driven operation and decision-making algorithms [15-17].

The operation of complex systems is so complicated that their complete dynamics would require a description that could match the complexity and extension of the whole system. Therefore, in order to examine them in a more simplified way, these system interactions will be described with the help of graph theory. The internal organization of such systems seems to be rather chaotic; it balances on the narrow border between complete order and complete chaos. Such "existence on the edge of chaos" [17] makes it difficult to apply the models based on rationality in research. Appropriate models are available to apply to systems which can be handled by traditional apparatus, for example the complexity of vehicles can be handled this way. However, self-organizing and dynamically and spontaneously changing systems, such as the technological 
ecosystem of a city, cannot be examined in a traditional way, only by the methods applying to complex systems. [16, 17]

The complexity of smart cities can be well demonstrated by Cohen's wheel as shown in Fig. 5. Cohen names six major areas in smart city implementations. These characteristics are the following: smart economy, smart government, smart mobility, smart environment, smart living and smart people. The complexity of the Smart City as a system is obvious.

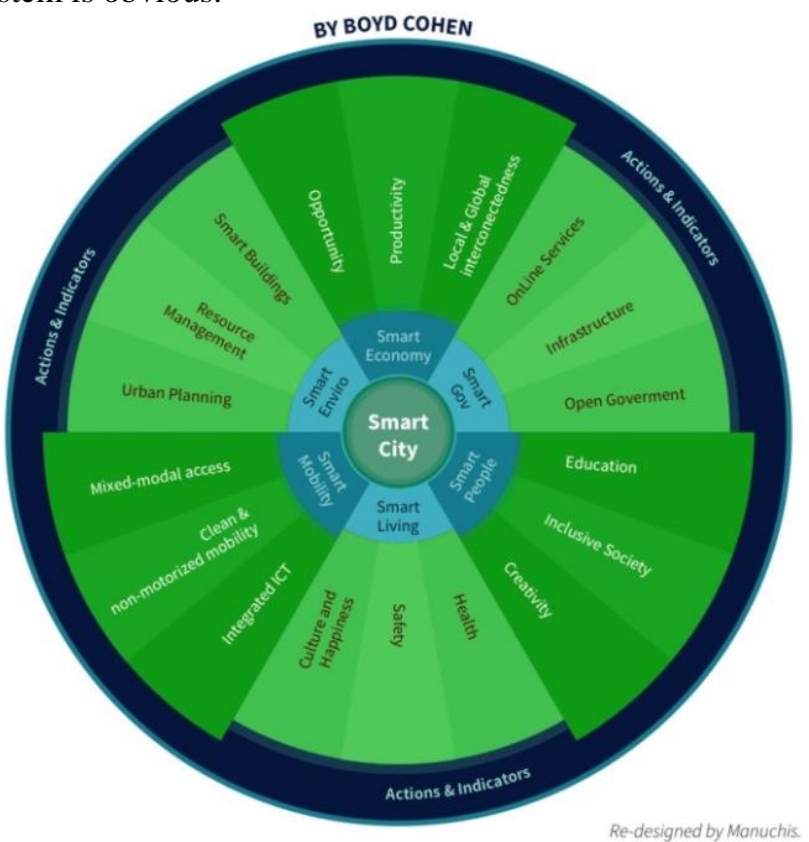

Fig. 5. Cohen's Wheel [18]

At this point, we must examine how the concept of "Smart City" can be defined and whether there is an internationally accepted definition. For example, the Smart City expert Robert Hollands recognized that the idea of smart city is a kind of an "urban labelling" phenomenon [19]. Various organizations, companies and researchers have defined the concept of "Smart City" in many different ways.

"Smart cities embrace technologically based solutions as an enabler of efficient, affordable and more sustainable urban living in times of resource scarcity, persistent austerity and high-tech innovations. However, cities' evermore complex systems are, albeit unwittingly, causing mismanagement, future uncertainty and lack of transparency to exacerbate their challenges." [20]

In his paper Komninos envisages "the rise of intelligent cities in the globalisation of innovation networks, which appears in multiple forms in global technology markets, innovation and $\mathrm{R} \& \mathrm{D}$ offshoring, global technology transfer, new product codevelopment and the subsequent needs for online environments of global collaboration." [10]

Deakin characterises the smart city in his book as "a city that utilises ICT to meet the demands of the market and community involvement in the process is necessary for a smart city" [21]. 
In a study issued in October 2014, the International Telecommunication Union (ITU) summarized the definitions related to Smart and sustainable cities. The result of the research was the summary of 116 different definitions into a single general definition of the smart city. The ITU's definition is the following: "A smart sustainable city (SSC) is an innovative city that uses information and communication technologies (ICTs) and other means to improve quality of life, efficiency of urban operation and services, and competitiveness, while ensuring that it meets the needs of present and future generations with respect to economic, social and environmental aspects."[22]

It is also important to define what exactly makes an urban system smart.

The International Organization for Standardization/ International Electrotechnical Commission Joint Technical Committee issued the following definition of "smartness" in 2014:

"The "smartness" of a city means its ability to bring together all its resources, to effectively and seamlessly achieve the goals and fulfil the purposes it has set itself. In other words, it describes how well all the different city systems, and the people, organisations, finances, facilities and infrastructures involved in each of them, are:

- individually working efficiently; and

- acting in an integrated way and coherent way, to enable potential synergies to be exploited and the city to function holistically, and to facilitate innovation and growth." [23]

"Smart can be defined as an implicit or explicit ambition of a city to improve its economic, social and environmental standards. The concept of smartness in terms of performance is highly relevant to technologically implementable solutions. In many cases, if there is some form of ICT, which is present in a city, the city or its activity is considered "smart". ICT devices and services are only an enabler or purveyor which allows the "smartness" to percolate throughout a system. Just by having a personal computer (PC) or smart phone does not define "smartness" or intelligence. Specifically, the International Organization for Standardizations (ISO) has recently released a report (ISO/TR 37150:2014) entitled: "Smart community infrastructures - Review of existing activities relevant to metrics". [23]

The studies of smart cities are gaining new grounds involving various disciplines. With the help of standardization a worldwide definition is becoming increasingly accepted and applied in this field of study. It is still a long way, however, until the definition of "Smart City" becomes an axiom like Ohm's law.

\section{Smart City standards}

The concept of "Smart City" is becoming more widely accepted at an international level. An increasing number of organizations and companies are recognizing the potential in this field. It is a huge business after all. All the big companies offer their own comprehensive solutions for municipalities. Having a closer look at the so-called "smart" cities, it can be stated that the picture is by no means complete with regards to the six characteristics. These cities only adapt certain individual solutions, therefore, the essence of the Smart City, that is the benefits gained from the co-operation of different systems, will be missing. For example, it does not make a city smart if all its vehicles are electrically driven. Electromobility only becomes part of a smart city, if the city's 
energy network and recharge infrastructure have a system-level relationship and communication [24]. It is necessary to maintain the energy balance of the Smart Grid (the energy network of the smart city). Electric vehicles are present in the city's life as mobile system elements. In order to create smart cities, it is necessary to build complex networks from the range of different systems. Therefore, it is not enough to integrate the electric vehicles into a smart power grid. Further connections must be made with other systems, such as the application for finding free places at parking lots with fast public charging stations [18]. Another connection point may be if the vehicles signal when they need service even before an error occurs [25].

Meanwhile several European and world-wide organizations for standardization are working on the elaboration of Smart City directives. Among these organizations the following institutes must be mentioned: DIN - German Institute for Standardization, CENELEC - European Committee for Electrotechnical Standardization, CEN European Committee for Standardization, ETSI - European Telecommunications Standards Institute, ISO - International Organization for Standardization, ISO/IEC JTC 1 - International Organization for Standardization/ International Electrotechnical Commission Joint Technical Committee Information technology, ITU (International Telecommunication Union) Telecommunication Standardization Sector.[26]

The complexity of the Smart City is well represented by the interrelationship of different standards, as the systems that are present in these cities cover all aspects of life.

The ISO technical committees responsible for the elaboration of Smart City standards [27]:

- ISO/TC 268 - Sustainable development in communities

- ISO/TC 268/CAG 01 - Chairman Advisory Group

- ISO/TC 268/SC 01 - Smart community infrastructures

- ISO/TC 268/SC 01/AHG 02 - Best practice guidelines for transportation

- ISO/TC 268/SC 01/AHG 03 - Case studies and recommendations with respect to the information sharing between multiple community infrastructures

- ISO/TC 268/SC 01/TG 01 - Roadmap

- ISO/TC 268/SC 01/WG 01 - Infrastructure metrics

- ISO/TC 268/SC 01/WG 02 - Integration and interaction framework for smart community infrastructures

- ISO/TC 268/TG 01 - Awareness-raising, communication and promotion

- ISO/TC 268/WG 01 - Management System Standards

- ISO/TC 268/WG 02 - City indicators

- ISO/TC 268/WG 03 - Vocabulary

Therefore, smart cities implementations are now supported by various international standards. The ISO TC 268 (Technical committee (TC), Subcommittees (SC), Working groups (WG), Task groups (TG), Ad-Hoc Group (AHG), Chairman Advisory Group $(\mathrm{CAG})$ ) under the title "Sustainable development in communities" deal with the elaboration of international Smart City standards. Since the creation of the parent organization 268 in 2012, three standards have been published thanks to their work.

Published standards [28]: 
- ISO 37120:2014 - Sustainable development of communities. Indicators for city services and quality of life.

- ISO/TR 37150:2014 - Smart community infrastructures. Review of existing activities relevant to metrics.

- ISO/TS 37151:2015 - Smart community infrastructures. Principles and requirements for performance metrics.

Abbreviations: Technical Report (TR), Technical Specification (TS)

In the forthcoming years important standardization efforts will be made in relation to smart cities. According to the available information, intensive preparatory work is in progress to issue further standards.

Further standards under development [29]:

- ISO/DIS 37101 - Sustainable development of communities. Management systems. Requirements with guidance for resilience and smartness.

- ISO/DIS 37102 - Sustainable development and resilience of communities. Vocabulary.

- ISO/AWI 37104 - Sustainable development in communities. Guide to establishing strategies for smart cities and communities.

- ISO/WD 37120 - Sustainable development of communities. Indicators for city services and quality of life.

- ISO/DTR 37121 - Inventory and review of existing indicators on sustainable development and resilience in cities

- ISO/NP 37122 - Sustainable development in communities. Indicators for Smart Cities.

- ISO/DTR 37152 - Smart community infrastructures. Common framework for development and operation. Ad hoc group report.

Abbreviations: Draft International Standard (DIS), Approved Work Item (AWI), Draft Technical Report (DTR)

\section{Overview of smart technologies opportunities in support of Smart Cities}

As it was discussed at the IEEE Smart Cities Conferences and the Emerging Information and Technology Conference, Smart City research and development can involve more than 160 thematic areas. We have listed some major areas below. We have carried out our studies in these areas. This list also clearly shows the possible trends of standardisation.

There were a lot of areas of Smart City developments discussed at the Emerging Information and Technology Conference [11]. For reasons of limited space of the present article, from the above-mentioned technologies we focus on Cyber-physical systems, as they can have a fundamental role the implementation of the other systems. 


\section{Cyber-physical systems (CPS)}

"Embedded systems have always been held to a higher reliability and predictability standard than general-purpose computing. Consumers do not expect their TV to crash and reboot. They have come to count on highly reliable cars, where in fact the use of computer controller has dramatically improved both the reliability and efficiency of the cars. In the transition to CPS, this expectation of reliability will only increase. In fact, without improved reliability and predictability, CPS will not be deployed into such applications as traffic control, automotive safety, and health care." [62]

Smart City research must also examine the roles of various cyber-physical systems. Today's cities have not only physical, but also virtual/cyber infrastructures. CyberPhysical Systems are such systems which connect the virtual world with the physical world with the help of embedded systems and infocommunication systems.

Lee et al. writes the following in his book: "A cyber-physical system (CPS) is an integration of computation with physical processes whose behavior is defined by both cyber and physical parts of the system. Embedded computers and networks monitor and control the physical processes, usually with feedback loops where physical processes affect computations and vice versa." [63]

Besides the meaning of CPS, the meaning of embedded systems must also be discussed here. According to Noergaard an embedded system (applied computer system) must have certain characteristics. These characteristics are, for example, the devices of dedicated functionality which meet high quality and reliability requirements. Their functionality is much more limited than that of an industrial PC, but their reliability is much higher [64].

Urban systems can be divided into a virtual and a physical part. For example, according to $\mathrm{Bu}$ et al., the smart grid is such an infrastructure, too: "The smart grid is composed of a pair of infrastructures: a physical infrastructure and a cyberinfrastructure. The electrical energy flows over the physical infrastructure. The cyber infrastructure is a large number of communication and computing networks, including wide-area monitoring, two way communications and enhanced control functions, which allows the interaction and feedback of socio-economic networks through the energy market.'"[65]

The differentiation between the virtual/cyber and the physical parts of various systems is, therefore, a real issue. It is enough to think about technical or physical infrastructures of different urban services, e.g. information technology systems, communication systems, energy systems, transport systems, etc. and their physical and virtual perspectives. From this aspect, these are all two-component systems. At the same time, by self-organization these traditional systems can develop those smart characteristics (e.g. smart transport) which are the basic requirements of smart cities (see the six characteristics by Cohen).

\section{Safety and security in smart cities}

"Modern society depends on sophisticated infrastructures to carry out its day-to-day activities. Such infrastructures includes buildings (e.g., homes, factories, offices, schools, shopping malls, etc.), utility networks (e.g., electricity, water, gas, sewage, 
etc.), transportation networks (e.g., roads, railroads and stations, harbors, shipping channels and yards, airports, etc.), transport vehicles (trains, planes, buses, etc.), food and goods distribution networks, healthcare delivery systems, information technology (IT) networks, and so on. Efficient management of these physical and/or cyber infrastructures not only involves sophisticated control systems, but also computing and communication paradigms (see Fig. 6). Control of large-scale entities such as transportation systems could involve integrated communication, computing and control over wide geographic areas. The IT systems themselves play a dual role in this context: they have an associated physical infrastructure that needs to be conFig.d, managed, and protected. Yet, the IT infrastructure leads to a complex cyber world that helps control cyber-infused physical infrastructures." [66]

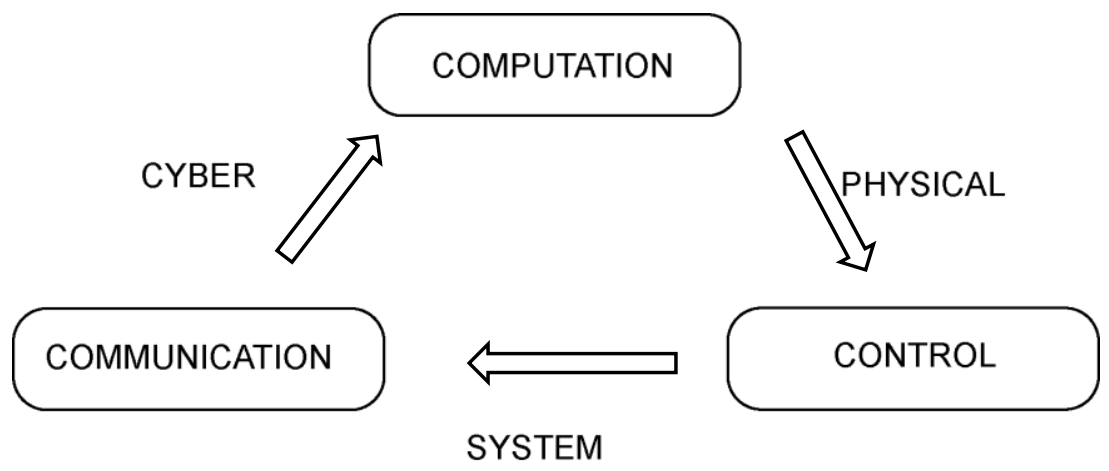

Fig. 6. The relationship between the cyber and physical world [66]

Forrester defines the Smart City as "The use of Smart Computing technologies to make the critical infrastructure components and services of a city - which include city administration, education, healthcare, public safety, real estate, transportation, and utilities - more intelligent, interconnected, and efficient." [8]

"Based on the "digital city", "smart city" is widely used in daily livelihood, environmental protection, public security, city services and other fields." [67]

The interdependencies of systems in smart cities have a significant effect on the operation of the overall system. With the digitalization of the world and the interlocking of different systems, greater attention must be paid to safety and security. The creation of safe societies requires more than ensuring the protection of critical infrastructures. The EU strategy called "Horizon 2020" also includes Disaster-Resilience - DRS, Fight against Crime and Terrorism - FCT, Border Security and External Security - BES and Digital Security - DS. The safety and security of the systems connecting the physical and virtual world will become more important in proportion with their increased use. This is because any flaw in their operation can have an instant effect on the safety of cities and the quality of life. Their disruption can affect the characteristics of smart cities defined by Cohen. 


\section{Summary: The smart industrial revolution}

The present study has summarized the driving forces behind Smart City implementations, and the benefits of the holistic smart city. It has also discussed the relevant Smart City standards. It is clear that further standards are needed and they should be issued soon considering the following studies.

In our opinion, the technologies relating to smart cities, for example cyber-physical systems, will play a significant role in the technical and economic life in the world. Thus, the increased use and market share of intelligent and smart systems will generate a new industrial revolution [68]. Not only infrastructures, transport systems and cities, but the whole world will become smart, which, in other words, will mean the smart of everything (evaluation of the smart revolution [68]).

\section{References}

1. Mind Commerce, Industrial Convergence Revolution: Smart Cities, Industry 4.0, Big Data in Manufacturing, and Industrial IoT, (2015), [Online]. Available: https://www.reportbuyer.com/product/3035901/industrial-convergence-revolution-smartcities-industry-4-0-big-data-in-manufacturing-and-industrial-iot.html

2. United Nations - Department of Economic and Social Affairs: World Economic and Social Survey 2013, Sustainable Development Challenges. [Online]. Available: https://sustainabledevelopment.un.org/content/documents/2843WESS2013.pdf, ISBN 978 -92-1-10 9167- 0

3. ITU-T Focus Group on Smart Sustainable Cities: An Overview of Smart Sustainable Cities and the Role of Information and Communication Technologies (ICTs). (10/2014) [Online]. Available: https://www.itu.int/en/ITU-

T/focusgroups/ssc/Documents/Approved_Deliverables/TR-Overview-SSC.docx

4. United Nations: World Population Prospects - The 2015 Revision. p.2. [Online]. Available: http://esa.un.org/unpd/wpp/publications/files/key_findings_wpp_2015.pdf

5. United Nations Department of Economic and Social Affairs Population Division, Growth rates of urban agglomerations by size class 2014-2030. [Online]. Available: http://esa.un.org/unpd/wup/Maps/CityGrowth/2014 2030GrowthRate.pdf

6. United Nations: World Urbanization Prospects -The 2014 Revision, 7 p. [Online]. Available: http://esa.un.org/unpd/wup/FinalReport/WUP2014-Report.pdf

7. The World Bank: Urban population (\% of total). [Online]. Available: http://data.worldbank.org/indicator/SP.URB.TOTL.IN.ZS/countries/1W-HUEU?display=graph

8. Washburn, D., Sindhu, U., Balaouras, S., Dines, R.A., Hayes, N., Nelson, L.E.: Helping CIOs understand "smart city" initiatives. Growth, Vol.17, No.2. (2009) Available: http://www.uwforum.org/upload/board/forrester_help_cios_smart_city.pdf

9. Nam, T., Pardo, T. A.: Conceptualizing smart city with dimensions of technology, people, and institutions. In Proceedings of the 12th Annual International Digital Government Research Conference: Digital Government Innovation in Challenging Times, 282-291. (2011). ACM. ISBN: 978-1-4503-0762-8

10. Komninos, N.: Intelligent cities: towards interactive and global innovation environments', Int. J. Innovation and Regional Development, Vol. 1, No. 4, 337-355. (2009)

11. Neirotti, P., De Marco, A., Cagliano, A.C., Mangano, G., Scorrano, F.: Current trends in Smart City initiatives: Some stylised facts. Cities, Vol. 38, 25-36. (2014). ISSN 0264-2751, http://dx.doi.org/10.1016/j.cities.2013.12.010 
12. Townsend, A.: Smart cities : Big data, civic hackers, and the quest for a new utopia (First ed.). New York, NY : W.W. Norton \& Company, Inc., ISBN 9780393082876. (2013)

13. Jain, R.: Smart Cities: Technological Challenges and Issues. Washington University in Saint Louis, (2015). [Online]. Available: http://www.cse.wustl.edu/ jain/talks/ftp/smrtcit.pdf

14. Kitchin, R.: The real-time city? Big data and smart urbanism. GeoJournal, Vol.79, No.1, 114., ISSN: 0924-5499, doi: 10.1007/s10708-013-9516-8. (2014)

15. Bowerman, B., Braverman, J., Taylor, J., Todosow, H., Von Wimmersperg, U.: The vision of a smart city. In Proceedings of the 2nd International Life Extension Technology Workshop, Paris. (2000)

16. Dezső, F.: Rendszertechnika, Szent István Egyetem (2011). [Online]. Available: http://www.tankonyvtar.hu/hu/tartalom/tamop412A/20100019_Rendszertechnika/index.html

17. Tamás, V.: Egyszerű és bonyolult - fogalmak és mértékek mesterséges és élő rendszerekben, Komplexitás-elmélet Magyar Tudomány, A Magyar Tudományos Akadémia lapja (2003). [Online]. Available: http://www.matud.iif.hu/03mar/vicsek.html

18. Cohen, B.: The Smartest Cities In The World 2015: Methodology. (2015). [Online] Available: $\quad$ http://www.fastcoexist.com/3038818/the-smartest-cities-in-the-world-2015methodology

19. Hollands, R. G., Will the real smart city please stand up? Intelligent, progressive or entrepreneurial?. City, Vol.12, No.3, 303-320. (2008)

20. Cavada, M., Hunt, D.V. and Rogers, C.D.: Do smart cities realise their potential for lower carbon dioxide emissions? In Proceedings of the Institution of Civil Engineers - Engineering Sustainability, ISSN 1478-4629, doi: 10.1680/jensu.15.00032

21. Deakin, M.: From intelligent to smart cities. Smart Cities: Governing, Modelling and Analysing the Transition. Taylor and Francis, 15. ISBN 978 - 1135124144

22. International Telecommunication Union, Smart sustainable cities: An analysis of definitions. [Online]. Available: https://www.itu.int/en/ITUT/focusgroups/ssc/Documents/Approved_Deliverables/TR-Definitions.docx

23. ISO/IEC JTC 1 Information technology, Smart cities Preliminary Report 2014. [Online] Available: $\mathrm{http} / / / \mathrm{www}$. iso.org/iso/smart_cities_report-jtc1.pdf

24. D’Elia, A., Viola, F., Montori, F., Di Felice, M., Bedogni, L., Bononi, L., Borghetti, A., Azzoni, P., Bellavista, P., Tarchi, D., Mock, R.: Impact of Interdisciplinary Research on Planning, Running, and Managing Electromobility as a Smart Grid Extension. IEEE Access, Vol.3, 2281-2305. (2015). doi: 10.1109/ACCESS.2015.2499118

25. Budai, D.: Next Generation Service Process for Premium Cars - The J5 Service System; In: Michael Schenk (szerk.) 8th International Doctoral Student Workshop on Logistics, 71-76. (2015). ISBN:978-3-944722-29-0

26. Lonien, J.: Technical Standards in the city context: OUTDATED CONCEPT OR ENABLER?. DIN - German Institute for Standardization. Slideshow. (2015). [Online]. Available: $\quad$ http://www.eera-sc.eu/sites/eerasc.eu/files/attachments/smart_cities_and_standardization_joachim_lonien_2015-11-19.pdf

27. ISOTC home, Enterprise Workspace ISO Standards Development, Committee ISO/TC 268 "Sustainable development in communities". [Online]. Available: http://isotc.iso.org/livelink/livelink?func=11\&objId=12236361\&objAction=browse\&sort=na $\underline{\mathrm{me}}$

28. Standards catalogue ISO/TC 268 - Sustainable development in communities, Published standards. [Online]. Available: http://www.iso.org/iso/home/store/catalogue_tc/catalogue tc_browse.htm?commid=656906 \&published $=$ on \&includesc $=$ true

29. Standards catalogue ISO/TC 268 - Sustainable development in communities, Standards under development.

[Online].

Available: 
http://www.iso.org/iso/home/store/catalogue_tc/catalogue_tc_browse.htm?commid=656906 \&development $=$ on \&includesc $=$ true

30. Naphade, M., Banavar, G., Harrison, C., Paraszczak, J., Morris, R.: Smarter Cities and Their Innovation Challenges. Computer, Vol. 44, No. 6, 32-39. (2011). ISSN 0018-9162, doi: 10.1109/MC.2011.187

31. Tokody, D., Schuster, Gy., Papp, J.: Smart City, Smart Infrastructure, Smart Railway. In Proceedings of the International Conference on Applied Internet and Information Technologies, 231-234. (2015). ISBN:978-86-7672-260-0

32. Harrison, C., Donnelly, I.A.: A Theory of Smart Cities. In Proceedings of the 55th Annual Meeting of the International Society for the Systems Sciences. (2011). ISSN 1999-6918

33. National Protection And Programs Directorate Office of Cyber And Infrastructure Analysis, The Future Of Smart Cities: Cyber-Physical Infrastructure Risk, (2015). [Online]. Available: https://ics-cert.us-cert.gov/sites/default/files/documents/OCIA\%20\%20The\%20Future\%20of\%20Smart\%20Cities\%20-\%20CyberPhysical\%20Infrastructure\%20Risk.pdf

34. Tokody, D., Schuster, Gy.: I2 - Intelligent Infrastructure. In: Gabriela Kristová; Peter Schmidt; Miroslav Hudec; Janette Brixová; Mária Szivosová; Pavol Jurík (ed.) Proceedings of the 5-th International Scientific Videoconference of Scientists and $\mathrm{PhD}$. students or candidates: Trends and Innovations in E- business, Education and Security, Bratislava, Szlovákia, 121-128. (2015). ISBN 978-80-225-4191-6

35. Chou, T.: Remote Sensing and Smart City. WIT Press, ISBN 978-1784660291. (2015).

36. Batagan, L.: Indicators For Economic And Social Development of Future Smart City. Journal of Applied Quantitative Methods, Vol. 6, No. 3, 27-34. (2011). ISSN 1842-4562

37. Kitchin, R.: The real-time city? Big data and smart urbanism. Geo Journal, Vol. 79, No. 1, 114. (2014). ISSN 0343-2521, doi: 10.1007/s10708-013-9516-8.

38. Nyikes Z., Rajnai, Z.: Big data, as part of the critical infrastructure. In Proceedings of the IEEE 13th International Symposium on Intelligent Systems and Informatics (SISY) Subotica, 217-222. (2015). doi: 10.1109/SISY.2015.7325383

39. Elmaghraby, A.S., Losavio, M.M.: Cyber security challenges in Smart Cities Safety, security and privacy. Journal of Advanced Research, Vol. 5, No. 4, 491-497. (2014). ISSN 20901232, doi:10.1016/j.jare.2014.02.006.

40. Su, K., Li, J., Fu, H.: Smart city and the applications. In Proceedings of the 2011 International Conference on Electronics, Communications and Control (ICECC), Zhejiang, $1028-1031$.

ISBN 978-1-4577-0320-1, doi: 10.1109/ICECC.2011.6066743

(2011)

41. Cosgrave, E., Tryfonas, T.: Exploring the Relationship Between Smart City Policy and Implementation. Smart Systems, Devices and Technologies (SMART 2012), Stuttgart, Germany, 79-82. (2012). ISBN 978-1-61208-225-7

42. Tambouris, E., Scholl, H.J., Janssen, M.F.W.H.A., Wimmer, M.A., Tarabanis, K., Gascó, M., Klievink, A.J., Lindgren, I., Milano, M., Panagiotopoulos, P. and Pardo, T.A.: Electronic Government and Electronic Participation. IOS Press. (2015)

43. Wan, J., Li, D., Zou, C., Zhou, K.: M2M Communications for Smart City: An Event-Based Architecture. In Proceedings of the IEEE 12th International Conference on Computer and Information Technology (CIT), Chengdu, 895-900. (2012). doi: 10.1109/CIT.2012.188

44. Tokody, D.: Smart Mobility. In: Bitay Enikő (Ed.) Proceedings of the 21-th International Scientific Conference of Young Engineers, Kolozsvár, Románia, 401-404. (2016)

45. Tokody, D., Schuster, Gy., Papp, J.: Study of how to implement an intelligent railway system in Hungary. In Proceedings of the IEEE 13th International Symposium on Intelligent Systems and Informatics (SISY) - Subotica, 199-204. (2015). doi: 10.1109/SISY.2015.7325379

46. Tokody, D., Papp, J., Schuster, Gy.: The challenges of the intelligent railway network implementation: Initial thoughts from Hungary. In: László Gogolák, Igor Fürstner (Eds.) 
Proceedings of the 3rd international conference and workshop Mechatronics in Practice and Education, Szabadka, Szerbia. 179-185. (2015). ISBN 978-86-918815-0-4

47. Tokody, D. Maros, D., Schuster, Gy., Tiszavölgyi, Z.: Communication-based intelligent railway - Implementation of GSM-R system in Hungary. In Proceedings of the IEEE 14th International Symposium on Applied Machine Intelligence and Informatics (SAMI), Herlany, 99-104. (2016). doi: 10.1109/SAMI.2016.7422989

48. Sallai, G.: Future Internet Visions and Research Clusters. Acta Polytechnica Hungarica, Vol. 11, No. 7, 5-24. (2014). ISSN: 1785-8860, doi: 10.12700/APH.11.07.2014.07.1

49. Gubbi, J., Buyya, R., Marusic, S., Palaniswami, M.: Internet of Things (IoT) A vision, architectural elements, and future directions. Future Generation Computer Systems, Vol. 29, No. 7, 1645-1660. (2013). ISSN 0167-739X, doi: 10.1016/j.future.2013.01.010

50. Ma, Y., Chowdhury, M., Sadek, A., Jeihani, M.: Real-Time Highway Traffic Condition Assessment Framework Using Vehicle-Infrastructure Integration (VII) With Artificial Intelligence (AI). IEEE Transactions on Intelligent Transportation Systems, Vol. 10, No. 4, 615-627. (2009). doi: 10.1109/TITS.2009.2026673

51. Khekare, G.S., Sakhare, A.V.: A smart city framework for intelligent traffic system using VANET. In Proceedings of the 2013 International Multi-Conference on Automation, Computing, Communication, Control and Compressed Sensing (iMac4s), Kottayam, 302305. (2013). doi: 10.1109/iMac4s.2013.6526427

52. Sino-Singapore Tianjin Eco-City, smart grid, smart city, In Proceedings of the 2012 IEEE PES Innovative Smart Grid Technologies (ISGT), Washington DC, 1-1. (2012). ISBN 978-14577-2158-8, doi: 10.1109/ISGT.2012.6175618

53. Atasoy, T., Akınç, H.E., Erçin, Ö.: An analysis on smart grid applications and grid integration of renewable energy systems in smart cities. In Proceedings of the 2015 International Conference on Renewable Energy Research and Applications (ICRERA), Palermo, 547-550. (2015). doi: 10.1109/ICRERA.2015.7418473

54. Su, K., Li, J., Fu, H.: Smart city and the applications. In Proceedings of the 2011 IEEE International Conference on Electronics, Communications and Control (ICECC), 1028-1031. (2011)

55. Geller, A.L.: Smart Growth: A Prescription for Livable Cities. American Journal of Public Health, Vol. 93, No. 9, 1410-1415. (2003). ISSN 1541-0048, doi: 10.2105/AJPH.93.9.1410

56. Khekare, G.S., Sakhare, A.V.: A smart city framework for intelligent traffic system using VANET. In Proceedings of the 2013 International Multi-Conference on Automation, Computing, Communication, Control and Compressed Sensing (iMac4s), Kottayam, 302 305. (2013). doi: 10.1109/iMac4s.2013.6526427

57. Kylili, A., Fokaides, P.A.: European smart cities The role of zero energy buildings. Sustainable Cities and Society, Vol. 15, 86-95. (2015). ISSN 2210-6707

58. Hao, L., Lei, X., Yan, Z., ChunLi, Y.: The application and implementation research of smart city in China. In Proceedings of the 2012 International Conference on System Science and Engineering (ICSSE), Dalian, Liaoning, 288-292. (2012). doi: 10.1109/ICSSE.2012.6257192

59. Davis, J., Edgar, T., Porter, J., Bernaden, J., Sarli, M.: Smart manu facturing, manufacturing intelligence and demand-dynamic performance. Computers \& Chemical Engineering, Vol. 47, $\quad$ No. 20, 145-156. (2012). ISSN $\quad$ 0098-1354, http://dx.doi.org/10.1016/j.compchemeng.2012.06.037

60. Jamil, M.S., Jamil, M.A., Mazhar, A., Ikram, A., Ahmed, A., Munawar, U.: Smart Environment Monitoring System by Employing Wireless Sensor Networks on Vehicles for Pollution Free Smart Cities. Procedia Engineering, Vol. 107, 480-484. (2015). ISSN 18777058, http://dx.doi.org10.1016j.proeng.2015.06.106

61. Gurgen, L., Gunalp, O., Benazzouz, Y., Gallissot, M.: Self-aware cyber-physical systems and applications in smart buildings and cities. In Proceedings of the Design, Automation \& Test in Europe Conference \& Exhibition (DATE), Grenoble, France, 1149-1154. (2013). doi: 10.7873/DATE.2013.240 
62. Lee, E.A.: Cyber Physical Systems: Design Challenges. In Proceedings of the 11th IEEE International Symposium on Object Oriented Real-Time Distributed Computing (ISORC), Orlando, FL, 363-369. (2008). doi: 10.1109/ISORC.2008.25

63. Lee, E.A., Seshia, S.A.: Introduction to Embedded Systems, A Cyber-Physical Systems Approach, Second Edition. p.1. [Online]. Available: http://LeeSeshia.org , ISBN 978-1-31242740-2

64. Noergaard, T.: Embedded Systems Architecture, 2nd Edition, Elsevier, p.768. (2012). ISBN 9780123821966

65. Bu, S., Yu, F.R.: A game-theoretical scheme in the smart grid with demand-side management: Towards a smart cyber-physical power infrastructure. IEEE Transactions on Emerging Topics in Computing, Vol.1, No.1, 22-32. (2013). doi: 10.1109TETC.2013.2273457

66. Das, S.K., Kant, K., Zhang, N.: Handbook on securing cyber-physical critical infrastructure. Elsevier. (2012). ISBN 9780124158153, doi: 10.1016/B978-0-12-415815-3.00035-2

67. Su, K., Li, J., Fu, H.: Smart city and the applications. In Proceedings of the 2011 International Conference on Electronics, Communications and Control (ICECC), Zhejiang, 1028-1031. (2011). ISBN: 978-1-4577-0320-1, doi: 10.1109/ICECC.2011.6066743

68. Mitomo, H., Fuke, H., Bohlin, E.: The Smart Revolution Towards the Sustainable Digital Society: Beyond the Era of Convergence. Edward Elgar Publishing Ltd. (2015). doi: $10.4337 / 9781784710040$ 